\title{
Revolution and Warfare: The North Before Conquest
}

\begin{abstract}
This chapter lays the foundation for an understanding of Napoleonic governance in the Netherlands and Northwest Germany. Dutch and German lands were governed in many different ways in the early modern age. During the eighteenth century attempts at reform were made in both areas, with varying results. The French Revolution was both admired and feared, especially as it became clear that the 'liberation' of Europe entailed aggressive expansionism. France's growth showed the difficulties of imposing rules and practices on a hitherto foreign population. Which policies were effective, which not? True, German secularization and mediatization (the historic Reichsdeputationshauptschluss of 1803), and repeated coup d'états in the Batavian Republic, restructured governance on the right bank of the Rhine. Yet, both in the Netherlands and Northwest Germany, the combination of awe of, and fear for, the French Empire strengthened identity formation, whether local, regional, or national, which was not necessarily beneficial for future integration into France.
\end{abstract}

Keywords Absolutism • Republicanism • Revolution • Warfare • Identity formation 


\section{Warfare ANd the Shaping of Nation-states}

French interventions in Northwestern Europe in the years leading up to Napoleon's ascension to the imperial throne, caused drastic reorganizations of countries and societies. Millions of people changed state, and would repeatedly do so until after the definitive fall of Napoleon. During the process clashes occurred between longstanding traditions and revolutionary novelties. Yet, well before the Revolutionary period, the Netherlands and Northwest Germany were affected by waves of reformist thought. There were, however, significant differences in the extent of each region's revolutionary fervor, and the ways ideas translated into actual reforms. Political conjuncture, international relations, and the perseverance of traditional structures, thwarted change.

Dutch and German internal affairs were greatly complicated when Revolutionary France redefined warfare. Under the creed of ridding the peoples of Europe from 'despots', liberation, conquest, and exploitation went hand in hand. The old modes of military conflict and diplomacy gave way to new types of forms, in which nation-building and empire-building came to the fore.

Smaller states within the borders of France, such as Nice and the former papal enclaves, had been incorporated at an early stage, but when Revolutionary France went on the offensive, major geopolitical transformations ensued. The northwest corner of continental Europe had further acquainted itself with French expansionism around 1795, when the French troops conquered many parts on the Left bank of the Rhine and started incorporating present-day Belgium and the Rhineland. The integration of both areas is especially significant given the fact that the French experiences in these newly conquered lands would affect how Napoleonic governance would be later introduced in the Dutch and Northwest German departments.

By discussing the pre-Revolutionary and Revolutionary periods in the lands north of Old France, this chapter lays the foundation for a proper understanding of Napoleonic governance in the Netherlands and Northwest Germany.

\section{Absolutism and Republicanism}

Present-day Netherlands and Northwest Germany were very heterogeneous during the early modern period. The origins of the Dutch state can be traced back to the revolt against Habsburg rule. When loyalty to the 
Spanish king Philip II was formally renounced, the United Provinces of the Netherlands, or Dutch Republic (1579-1795), was set up as a confederation of seven autonomous provinces. The provinces enjoyed a substantial degree of self-rule. Each sent delegates to the States-General in The Hague. Initially, the States-General became responsible for chiefly military and foreign matters. But quickly, their decisions came to apply to a wider sphere of government. Apart from the Provinces, the Dutch Republic also comprised so-called Generality Lands, ruled by the States-General. No delegates from these areas-with a predominantly Catholic population-were represented in The Hague. In practice, contrary to the republican ideal of equality, not all Provinces were equally powerful. The States of Holland dominated the Republic. And within the Province of Holland, Amsterdam soon became the most influential city.

Another binding factor were the Stadtholders. These nobles had been originally representatives from the Habsburg Emperor. One of them, William of Orange, had played a major role during the Revolt. From that moment, as no monarch could mediate between provinces, the individual Provincial States appointed Stadholders. These officials—often provinces chose different Stadholders-commanded the army, but also functioned as highest office-holders. In many towns the Stadtholder selected urban magistrates. In short, the Dutch Republic at a first glance was a league of sovereign provinces, but in fact was a unique political entity which operated as a powerful federal state. ${ }^{1}$

Meanwhile, the area that would later become the Northwest German part of the Napoleonic Empire, was still distributed over many independent states. The largest state was Hanover, or the Electorate of BrunswickLüneburg, which stretched from the North Sea to Central Germany, and also governed adjacent areas, such as the County of Bentheim. The British king ruled Hanover and the United Kingdom in a personal union. The Duchy of Oldenburg, around the city of the same name, was also a personal union, namely with the Prince-Bishopric of Lübeck. During the eighteenth century, the Kingdom of Prussia had acquired more and more territories in the West, such as the province of Ostfriesland and the County of Lingen. The Prince-Bishopric of Münster, was an ecclesiastical state, ruled by a bishop, who not only exercised spiritual power but also secular

\footnotetext{
${ }^{1}$ Jonathan Israel, The Dutch Republic. Its rise, greatness, and fall. 1477-1806 (Oxford 1998) 276-306.
} 
power. The same applied to the slightly smaller Prince-Bishopric of Osnabrück. Geographically much smaller, but long-time economic and political power factors, were the three Hanseatic cities (the Free Imperial Cities) of Lübeck, Bremen and Hamburg. In each, power was distributed between a Senate and Citizen's Councils. Notwithstanding subtle differences between cities, Hanseatic government, as in the Dutch Republic, was in essence collegial government, dominated mainly by urban merchant families. ${ }^{2}$

Unlike the Dutch, most of the inhabitants of Northwest Germany were affected by enlightened absolutism, which emerged during the second half of the eighteenth century. It envisaged a rational government safeguarding internal socioeconomic conditions. The idea of the droit divin gave way to a more secular approach to princely power, in which the promotion of societal happiness was the most fundamental task of the state. ${ }^{3}$ Ambitious enlightened monarchs also tried to profile themselves internationally, continuing the earlier absolutist pursuit of a large and efficient army and civil service. For example, King Frederick William I had already reformed governance in his kingdom, severely curtailing the autonomy of provincial and local rulers. King Frederick II retained his father's effective state apparatus and increased Prussia international standing. The state grew in importance, and therefore that of its embodiment: the prince, who could maintain absolute control to monitor the greater good. This notion of governance has been characterized as a 'teleocratic style of governance'.

In Northern Germany, Hanseatic city-states were islands of republicanism. There, civic tradition, Protestant aversion to exuberance, and new enlightened ideas went hand in hand, culminating in a variety of enlightened reforms. Respect for the city's history was part of civic communitybuilding and republican self-identification. This had a strong anti-aristocratic character, even more so than in Dutch republicanism

\footnotetext{
${ }^{2}$ Mary Lindemann, 'Voluntarism in social welfare and urban government: The case of Hamburg, 1700-1799', Journal of Urban History 36 (2010) 316-331. https://doi. org/10.1177/0096144209359143

${ }^{3}$ Elisabeth Fehrenbach, Vom Ancien Régime zum Wiener Kongress (4th ed.; München 2001) 55 .

${ }^{4}$ H. M. Scott, 'Introduction: The problem of enlightened absolutism', in: H. Scott ed., Enlightened absolutism: Reform and reformers in later eighteenth-century Europe (London 1989) 1-2, 16; Michael Spicer, 'Public administration: The history of ideas, and the reinventing government movement', Public Administration Review 64 (2004) 356. https:// doi.org/10.1111/j.1540-6210.2004.00379.x
} 
which — unlike the Hanseatic city-states—did not have to position itself vis-à-vis enlightened absolutist Princes. ${ }^{5}$

While many European states experienced centralizing tendencies, the Dutch Republic maintained its local particularistic state structure-a tightknit network of urban communities. Things changed at the end of the eighteenth century, with the Patriot movement of the 1780s. Following the military and economic decline of the Republic, republican patriots tried to reclaim what they thought were traditional rights. Having little say in political matters, the Patriots focalized their attention on the civic militias. Throughout the Republic, militias that had been dormant for decades, or centuries, were revived as symbols of civic pride. Middle-class patriots demanded that civic corporations, like militias and craft guilds, had to be consulted by the city government in public matters. Also, Patriots called for the election of urban councilors and town officials, as well as the right of (legislative) initiative. ${ }^{6}$

As many Dutch towns, the Hanseatic city-states developed a vivid public sphere, in the form of neutral enlightened societies, coffee houses, and reading societies, where citizens came together to discuss social issues. Gradually they formed a breeding ground for early democratic ideas. The most prominent enlightened society was the Patriotic Society (1765), in Hamburg, which was in close contact with the urban government, contributing to the reform of Hamburg's governance. Similar societies were established in many towns in Northwest Germany. ${ }^{7}$

As more and more Dutch towns and provinces embraced the Patriot cause, the Republic effectively was in a state of civil war. Following repressive actions of Stadtholder William V, factions within the Patriot movement started to call for popular sovereignty and new liberties, thus developing a new democratic republican discourse. This led to a rupture between moderate Patriots and democratic Patriots who increasingly attacked the perceived 'aristocratic' system of governance. ${ }^{8}$ In September

\footnotetext{
${ }^{5}$ Katherine Aaslestad, Place and politics: Local identity, civic culture and German nationalism in North Germany during the Revolutionary Era (Leiden 2005) 58-59, 67.

${ }^{6}$ N. C. F. van Sas, De metamorfose van Nederland. Van oude orde naar moderniteit, 1750-1900 (Amsterdam 2004) 214.

${ }^{7}$ Aaslestad, Place and politics, 68-75, 108-109.

${ }^{8}$ Mart Rutjes, 'Onderdrukt onbehagen. Het ontstaan van de repressieve staat in Nederland', in: P. van Dam, J. Turpijn and B. Mellink ed., Onbehagen in de polder. Nederland in conflict sinds 1795 (Amsterdam 2014) 25.
} 
1787, the Stadtholder-thanks to a military intervention of his Prussian brother-in-law Frederick II-regained his power. The unorganized Patriot militias were no match for a standing army. Urban governments and militias were purged of Patriots; many of whom fled to the Southern Netherlands or France, which caused a flight of capital.

Twenty years later, the counter-revolution played a part in discussions on the incorporation of the Netherlands. That William V had needed help from Prussian troops to overthrow the Patriots and re-impose his authority, was seen by Emperor Napoleon as a justification to incorporate the Netherlands. Effectively, the Dutch had already been conquered in 1787, Napoleon would argue (see Chap. 3).

Despite its military might, the Orangist counter-revolution of 1787 was not a real victory. In the long run, the repressive actions of the Stadholder only served to give the Patriot ideals more support. Remaining Patriots went underground in so-called reading societies. In spite of feelings of national solidarity, individual revolutionary groups were local in nature. ${ }^{9}$ This made more and more Dutch Patriots realize that a national movement was of great importance.

The enlightened German citizens called themselves 'Patriots', but Katherine Aaslestad has argued that 'public moralists' is a more precise term, since their point of view was mainly ethical, or moral in nature. ${ }^{10}$ Partly this also applies to the Dutch Patriots, but they gradually became more politicized, especially as some of them began to embrace progressive ideas about popular sovereignty. Dutch Patriots also had to take an explicit stance on the issue of local or provincial autonomy versus federal or national uniformity. Such an issue was one that hardly concerned Northwest German Patriots in 1780s.

While Stadholder William V was helped by his Prussian brother-in-law, French King Louis XVI struggled with political-theoretical criticism of philosophes, opposition to social and economic inequalities, and a mounting debt burden. This necessitated the convening of the États généraux (States-General) for the first time since 1614. The Third Estate called for a single assembly in which the citizenry would have a numerical majority, adorning itself with the title Assemblée nationale. The reluctant Louis XVI initially hesitated to intervene. In July and August, popular uprisings

${ }^{9}$ J. G. M. M. Rosendaal, Tot nut van Nederland: polarisatie en revolutie in een grensgebied, 1783-1787 (Nijmegen 2012) 237-238.

${ }^{10}$ Aaslestad, Place and politics, 97. 
showed the weaknesses of the monarchy. Louis XVI's reluctance hindered the establishment of a new constitutional framework. Due to his failed attempt to flee, in the summer of 1791, lack of unanimity among the revolutionaries, and constant war threat, the government steadily lost its grip on the population. Louis XVI, like Stadholder William V, had tried to appeal to the band of brothers-in-law to restore his authority, in his case Austrian Emperor Leopold II. The constitutional monarchy lost its credibility. After the adoption of the first French constitution in October 1791, dissatisfaction grew. When armed civilians entered the Palais de Tuileries on 10 August 1792, the constitutional monarchy was moribund. ${ }^{11}$

Subsequently, the brutality that characterized the rule of the powerful Committee of Public Safety, with Maximilien Robespierre as its most prominent member, culminated in an outburst of violence that claimed the lives of tens of thousands of French people, including Louis XVI and his family. The Terror had a decisive influence on the course of the French Revolution. Nationally, it made many people long for a definitive end to the revolution. Foreign sympathizers rarely could reconcile themselves with the extreme turn that the Revolution had taken. ${ }^{12}$ This was at odds with France's growing ambition to rid Europe of the Old Regime 'despots'.

For instance, in 1789 many educated German citizens had initially greeted the French Revolution, due to widespread dissatisfaction with the situation in Germany. There were also close personal ties with French revolutionaries and Hamburg in particular was a lively meeting place for international 'Jacobins', as conservatives derogatorily, called revolutionaries. ${ }^{13}$ On the one hand, there was a disappointment at the waning momentum of enlightened absolutism; on the other, worsening social conditions caused dissatisfaction. In particular in Northern Germany, which was a center of journalism and book publishing, a radical revolutionary movement arose that no longer only demanded freedom but also equality. While the Hamburg merchant citizenry was close to the Girondins, intellectuals and craftsmen sympathized with the Montagnards. For example, Jacobin Georg Conrad Meyer from Flensburg, in his periodical Der newe Mensch, propagated the equal distribution of goods, however nowhere in

\footnotetext{
${ }^{11}$ Annie Jourdan, La Révolution, une exception française? (Paris 2004) 49-50.

${ }^{12}$ Ibid., 371-374.

${ }^{13}$ Aaslestad, Place and politics, 118-122.
} 
Northern Germany were any genuine attempts made to put the principles of the French Revolution into practice. ${ }^{14}$

Although the Revolution was admired from afar, there was also fear for its potential consequences. Skepticism prevailed. The German lands were said not to be ripe for a revolution. Even Heinrich Würzer, one of Northern Germany's most famous 'Jacobins', understood revolution to be nothing more than reform. Civil disobedience was acceptable, but a bloody uprising had little to do with a real revolution, he argued. ${ }^{15}$ The violence of the First French Republic confirmed to civic Northwest Germans that the French lacked morality, and thus strengthened their belief in their own superiority. ${ }^{16}$

Dutch Patriots who had fled from the Republic to France, did not react unequivocally to the radicalization of the revolution. A small number of ultra-revolutionary exiles were in close contact with French kindred spirits, and united in the Comité Révolutionnaire Batave, hoping to reform the Dutch situation along French lines. However, Robespierre believed that the Dutch would not benefit from the French model as each people had its own customs and habits. Moreover, early 1793, the French had declared war on the Stadholder, thus justifying the war without compromising Dutch popular sovereignty. The majority of government members called for the usefulness of an independent Dutch Sister Republic. A small minority within the National Convention, however, believed that the Netherlands could simply be incorporated. ${ }^{17}$ Many Dutch Patriots therefore lost their enthusiasm for the French cause during this period. Conversely, many Jacobins were suspicious of, the in their eyes bourgeois, Dutchmen. $^{18}$

${ }^{14}$ Fehrenbach, Vom Ancien Régime, 65.

${ }^{15}$ Ibid., 61-63.

${ }^{16}$ Aaslestad, Place and politics, 127-129.

${ }^{17}$ Marc Belissa, "Faire la guerre au Stadhouder ou à la nation Hollandaise?': Le débat politique autour de la déclaration de guerre (décembre 1792-mars 1793)', in: A. Jourdan and J. Leerssen ed., Remous révolutionnaires: République batave, armée française (Amsterdam 1996) 69-80.

${ }^{18}$ Joost Rosendaal, “La liberté est une garce!' Les Bataves à Paris (1787-1795)', in: A. Jourdan and J. Leerssen ed., Remous révolutionnaires: République batave, armée française (Amsterdam 1996) 66-67. 


\section{EXPORTING THE REVOLUTION}

With the demise of the French monarchy, a long series of wars began that no longer involved the traditional balance of power, but placed the nation on a pedestal. The novelty of this concept of war lay in the fact that foreign policy could no longer be separated from domestic policy. Warfare acted as a nation-building instrument in a politically and socially divided France, turning into an outlet for internal tensions. Successive French revolutionary governments, prolonged and increased warfare, with growing missionary zeal. Defensive warfare turned into a war of liberation and conquest. The French threat was, however, not immediately recognized by European diplomats who only knew international power politics. ${ }^{19}$

In November 1792 French troops invaded the Austrian Netherlands, hoping to establish a Sister Republic. Officially, the Constitution of 1791 had determined that France renounced 'the undertaking of any war with a view to making conquests, and [would] never use its forces against the liberty of any people'. And also in the years that followed it was official policy that 'liberated' peoples should, in principle, retain existing laws and institutions. But the actual behavior of generals and officials in conquered lands was not always in line with that. ${ }^{20}$ The French thought that the Belgians, who were dissatisfied with their Habsburg sovereign, would be enthusiastic. Initially, Revolutionary France was indeed seen as a liberator, but it soon became apparent that opinions differed widely. Like the Dutch patriots of the $1780 \mathrm{~s}$, Belgians attached great value to the restoration of old, local privileges as protection against a centralist monarch. However, the French National Convention dismantled traditional bodies in December 1792 with the aim of an organization based on the French model. ${ }^{21}$ Moreover, in the North, military advances of General CharlesFrançois Dumouriez and Dutch exile Lieutenant-General Herman Willem Daendels were halted, and local support was meagre, forcing withdrawal. After a brief restoration of Austria's power, French troops finally prevailed in July 1794. A new Conseil de gouvernement, headed by

\footnotetext{
${ }^{19}$ Fehrenbach, Vom Ancien Régime, 42-46.

${ }^{20}$ Peter M. R. Stirk, 'The concept of military occupation in the era of the French Revolutionary and Napoleonic Wars', Comparative Legal History 3 (2015) 69-74. https:// doi.org/10.1080/2049677X.2015.1041726

${ }^{21}$ Brecht Deseure, "Etre libre de nom et esclave de fait'. De Brabantse constituties tijdens de Franse periode (Zuidelijke Nederlanden)', Noordbrabants Historisch Jaarboek 29 (2012) 349-369.
} 
Commissioner Louis-Ghislain de Bouteville, replaced extant governmental institutions and was to look after the implementation of the French system of governance in the nine 'Belgian' departments. Legal and administrative integration started, leading to rigorous reforms. Old Regime practices and institutions were abolished, and an end was put to all prerogatives of the Church. Consequently, many members of the Belgian elite lost their positions. With the introduction of elections, in 1797, the number of local administrators and magistrates increased, which somewhat improved the reputation of French governance and stimulated its acceptance. And when, with Napoleon's rise to power in 1799, the Commissioner in Brussels disappeared, the Belgian departments were truly organized along French lines. ${ }^{22}$

Concurrently, the German Rhineland was conquered. The Peace of Basel, of 5 April 1795, stated that the French would occupy the Rhineland momentarily. When peace would return, a definite arrangement would be made. However, the secret articles of the treaty prescribed that Prussia and France would eventually come to an exchange. The French relatively quickly insisted on obtaining the Rhineland, something that the French monarchs had never demanded so explicitly. The Prussian king would give up his rights in the Rhineland in return for territorial compensation elsewhere, which would have to be specified at a later date. ${ }^{23}$ A demarcation line was drawn, to the north of which all German states would remain neutral. The French promised not cross this line, thus increasing the influences of Prussia in Northern Germany.

In November 1797, four 'Rhenish' departments were established, with François Joseph Rudler as Commissioner to oversee their organization. From Parisians desks, the departments were further divided into districts, cantons, and municipalities, by the summer of $1798 .{ }^{24}$ What made the situation in the Rhineland complicated, was that unwilling local elites were not eager to support French rule, and French were uncertain how to deal with traditional prerogatives and social inequalities. Hesitations on the

${ }^{22}$ Dirk Heirbaut, 'De Franse overheersing in België', in: A. Berkvens, J. Hallebeek and A. Sirks ed., Het Franse Nederland: de inlijving 1810-1813. De juridische en bestuurlijke gevolgen van de 'Réunion' met Frankrijk (Hilversum 2012) 17-23.

${ }^{23}$ Josef Smets, 'Le Rhin, frontière naturelle de la France', Annales historiques de la Révolution française 314 (1998) 686-687, 697. https://doi.org/10.3406/ahrf.1998.2206

${ }^{24}$ Bernd Wunder, 'L'administration territoriale des départements allemands annexés par l'Empire napoléonien', in: M. Pertué ed., L'administration territoriale de la France (1750-1940) (Orléans 1998) 349-350. 
side of the French, combined with local resistance, led to a slow start of integration, creating an uncomfortable situation for the intermediary French administrations. ${ }^{25}$ Collaboration was not necessarily a signal that the population was fully accommodating to French rule. The French authorities had to comply with older patronage networks for strategic reasons. The French learn that existing practices could survive within the new system of governance. ${ }^{26}$ Effective governance was extra welcome when late 1798, drastic French measures, such as the restriction of the power of the Church and the introduction of conscription, led to popular resistance in Belgium and the Rhineland, the Boerenkrigg or Klüppelkrieg. Given the different local circumstances, the Belgian and German regions were incorporated in different tempi. It was not until 1801, when the great powers ratified the Treaty of Luneville, that the left bank of the Rhine was permanently incorporated. ${ }^{27}$

\section{Revolutionary Republicans in the North}

The Dutch Patriots, or 'Batavians' as they were increasingly called, witnessed how the French emerged as conquerors in Belgium and Germany, and expressed doubts about French intervention. Alexander Gogel (later member of the Napoleonic intermediary government in Amsterdam) recognized, on the eve of the Batavian Revolution, that support from France was indispensable, but was keen to prevent the Netherlands from being regarded as a pays conquis; in his eyes, wherever possible Dutchmen had to take the lead. ${ }^{28}$ With the invasion of French-Batavian troops (this time led by Jean-Charles Pichegru, with Dutch assistance by Daendels and Jan Willem de Winter) and in January 1795, Stadtholder William V fled to England, and all over the Dutch Republic, provincial and city governments were purged of Orangists. After the proclamation of the Batavian Republic, major differences of opinion emerged about what the new state should look like. Because of the devastating defeat that ended all patriot

\footnotetext{
${ }^{25}$ Smets, 'Le Rhin'.

${ }^{26}$ Michael Rowe, 'Between Empire and home town: Napoleonic rule on the Rhine, 1799-1814', The Historical Journal 42 (1999) 643-674. https://doi.org/10.1017/ S0018246X9900850X

${ }^{27}$ Kees Schaapveld, Bestuur en bestuurders in Nedermaas, 1794-1814: met bijzondere aandacht voor het lokale bestuur in het kanton Wittem/Gulpen (Hilversum 2017) 44.

${ }^{28}$ Jan Postma, Alexander Gogel (1765-1821): grondlegger van de Nederlandse staat (Hilversum 2017) 32-39.
} 
experiments in 1787, and the French Revolution, nearly all Batavian revolutionaries demanded a true unitary state. ${ }^{29}$ However, there was continual disagreement about the degree of participation of citizens and about how the state should be centralized. Paradoxically, the very democratic ideals that had mobilized the revolutionaries formed an obstacle for political reform. ${ }^{30}$

The optimism of the Dutch revolutionaries was tempered when the question of the future of the Batavian was raised. The French demanded compensation for their efforts: the Batavian Republic lost part of its territory in the South, it had to pay a sum of 100 million guilders to France, and maintain a French force. Mutual irritations soon caused dissatisfaction from both sides. Batavians wanted a friendly and commercial alliance, but were faced with a military alliance. They were offended by the French financial and military requirements which they saw as an attack on their autonomy. The French treated their revolutionary brothers with a high degree of prejudice and had little regard for the political sensitivities within the Batavian Republic. They often let their own interests prevail. However, the Batavians were also opportunistic, turning French interventions to their own advantage. ${ }^{31}$

In the years following France's expansion, the Hanseatic city-states benefited from their neutral status. Trade flourished. Especially Hamburg became an economic and financial center, at the expense of notably Amsterdam. But citizens realized that neutrality, without being backed by military power, was fragile. That Bremen was briefly occupied by Hanoverian and English troops demonstrated this, as did the growing Prussian ambitions in Northern Germany. That the cities were formally part of the anti-French Holy Roman Empire did not help either. On 11 May 1795, representatives from Hamburg, Bremen, and Lübeck convened in the first Hansetag (Hanseatic Conference) since 1669. The aim was to ensure Hanseatic neutrality, by emphasizing its positive effect for all European states, as a platform for free trade and prosperity. The

\footnotetext{
${ }^{29}$ Stephan Klein, 'De sprong naar '95. Van patriots naar Bataafs republikanisme', De Achttiende Eeuw 28 (1996) 39-46.

${ }^{30}$ See also Thomas Poell, The democratic paradox. Dutch revolutionary struggles over democratisation and centralisation (1780-1813) ( $\mathrm{PhD}$ thesis, University of Amsterdam 2007). https://dspace.library.uu.nl/handle/1874/22668

${ }^{31}$ Annie Jourdan, 'Le rôle des agents français dans la constitution batave de 1798', Annales historiques de la Répolution française 351 (2008) 99-119. https://doi.org/10.4000/ ahrf.11367
} 
cooperation forced by common dangers was accompanied by a program of regional identity formation. ${ }^{32}$

On 18 fructidor year V (5 September 1797) in France republicans seized power with the help of the army to counter the growing power of royalists. This coup, which showed the extent to which the army was becoming a decisive factor, prompted Dutch sympathizers to seek secret contact with the French. Supported by French troops, Batavians from the camp of the radical unitarians staged a coup d'état on 22 January 1798. The French ambassador Charles Delacroix had planned the coup together with mainly Amsterdam radicals. Moderate political opponents were imprisoned. Following an undemocratic referendum, a radical constitution was accepted that turned the Batavian Republic in a 'one and indivisible' unitary nation-state. Although the radical democratic government realized the ideals of a unitary state and civic liberties, at the same time it alienated a large part of the people from politics. In June 1798 the government was purged of radicals, and moderates regained power, yet the revolutionary constitution, and its accomplishments, were kept. ${ }^{33}$

\section{The First Consul and Europe}

General Bonaparte, after his Italian and Egyptian campaigns, came to power on 18 brumaire year VIII (9 November 1799). In the preceding year, Bonaparte became convinced he was the one who could regenerate the French Republic. Like many French citizens he was disillusioned with the Directory, given the defeats in the War of the Second Coalition, problems with conscription, and economic issues; to name but a few difficulties that severely hindered the effectiveness of the Directory. Politicians from different factions longed to revise the constitution but were in disagreement on how exactly to go about this. Together with Director Emmanuel Joseph Sieyès, who strived for a stronger executive without destroying the Republic, Napoleon Bonaparte had planned the coup d'état. Much has been written on 18 brumaire, for instance, on the role played by brother Lucien Bonaparte, the newly elected president of the Council of Five Hundred, who arranged the council's 'consent' that was needed to legitimize the coup. The coup showed that the military leader possessed

\footnotetext{
${ }^{32}$ Aaslestad, Place and politics, 204-210.

${ }^{33}$ Martijn van der Burg, Nederland onder Franse invloed. Culturele overdracht en staatsvorming in de napoleontische tijd, 1799-1813 (Amsterdam 2009) 44-45.
} 
political talents and was capable of appeasing different groups within society while pursuing his own program. ${ }^{34}$

The new French constitution of the year VIII, 25 December 1799, foresaw a supposedly democratic government. But Bonaparte was able to curtail democratic institutions, not least because he was supported by an antiparty, technocratic elite; a group which would form a rich source of Napoleonic state representatives. ${ }^{35}$ From the coup of brumaire on, legislation was made primarily in the newly created Conseil d'État, whose members were selected by Bonaparte. The Conseil d'État also nominated all high officials, such as prefects. The constitution introduced tricameralism; three legislative or parliamentary chambers were created: the Sénat conservateur, the Corps législatif and the Tribunat. Members of the highest and most important chamber, the Senate, were appointed for life by Bonaparte. Senators were mostly moderate veterans of the Revolution. They had at their disposal the procedure of sénatus-consultum, or sénatus-consulte which allowed the loyal Senate to approve constitutional changes proposed by the First Consul and thus bypass the already weak Legislative body and the Tribunate. ${ }^{36}$ Importantly, the instrument of the sénatusconsulte would be used frequently during the process of empire-building, specifically a sénatus-consulte organique which amended the constitution.

Via a plebiscite held on 7 February 1800 the French citizens entitled to vote officially accepted the new constitution, although the government tampered with the figures. Together with Jean-Jacques-Régis de Cambacérès and Charles-François Lebrun, Napoleon became Consul of the French Republic. As First Consul, Napoleon effectively ruled alone. Cambacérès and Lebrun had a purely consultative role. Cambacérès advised Bonaparte on legal matters, Lebrun on financial matters. In these two domains, the First Consul could use the assistance of experienced public servants. ${ }^{37}$

Napoleon inherited the ideological warfare policy of the Directory. Under the Directory, the idea of liberating Europe from feudal despots

\footnotetext{
${ }^{34}$ Annie Jourdan, L'empire de Napoléon (Paris 2000) 45-51; D. G. Wright, Napoleon and Europe (Harlow 1984) 16-18.

${ }^{35}$ Lynn Hunt, David Lansky, and Paul Hanson, 'The failure of the liberal republic in France, 1795-1799: The road to brumaire', The Journal of Modern History 51 (1979) 758-759. https://doi.org/10.1086/241988

${ }^{36}$ Geoffrey Ellis, The Napoleonic empire (2nd ed.; Basingstoke 2003) 24-25.

${ }^{37}$ Isser Woloch, Napoleon and his collaborators: The making of a dictatorship (New York 2001) 122-123.
} 
had changed into the wish to extend France to its presumed natural borders. In his days as general, Napoleon had been an ardent supporter of expansionist measures. As First Consul, his ambitions grew larger and increasingly ignored long-accepted frontiers. ${ }^{38}$ The notion of the Rhine as a natural border of France was not new. Long before the French Revolution, the idea existed that France could make historical claims on the (alleged) homeland of the Gauls, situated between the Pyrenees, the Alps and the Rhine, from 1792 onward was brought to the forefront again. ${ }^{39}$ The year 1799 saw the consolidation of French rule in annexed territories, like a protective layer shielding Old France. Plus, the First Consul took over from the Directory a seasoned army, an efficient system of conscription and an organized corps diplomatique. All this enabled him to develop his European offensive politics, disguised as defensive (protecting the Republic from foreign threats). ${ }^{40}$

The First Consul faced little opposition from within the government. Napoleon's Minister of the Exterior Charles-Maurice de Talleyrand (who had been appointed under the Directory, in 1797) was comfortable with the First Consul directing foreign policy. He was primarily interested in commercial and financial aspects. For instance, it was not him but Joseph Bonaparte who had a large role in the peace negotiations of 1800-1802. Nevertheless, during the incorporation of northern Italy, Talleyrand did object to the continuing expansion of the Empire. France had to perfect its system of governance before imposing it on Europe; better yet, France needed allies, not more territory, he argued..$^{41}$

In the Netherlands, revolutionary politicians from different parties, at first welcomed 18 brumaire. Some saw it as a return to the original liberal ideals of the Revolution, and assumed the former general, as a head of state, would pursue lasting peace. However, the First Consul primarily assessed the Dutch sister republic on its financial and military potential. Within a few weeks, Bonaparte demanded a financial contribution from the Sister Republic; in return, he would stimulate Dutch commerce. The First Consul was in great need of funds. In the end, the deal failed and

\footnotetext{
${ }^{38}$ Jourdan, L'empire de Napoléon, 113-114.

${ }^{39}$ Smets, 'Le Rhin', 676.

${ }^{40}$ Jacques-Olivier Boudon, 'L'Europe en 1800', in: T. Lentz ed., Napoléon et l'Europe (Paris 2005) 80-81.

${ }^{41}$ Emmanuel de Waresquiel, 'Talleyrand, une vision européenne', in: T. Lentz ed., Napoléon et l'Europe (Paris 2005) 134-135.
} 
Napoleon would never forget the 'arrogance' of the 'wealthy' Dutch. ${ }^{42}$ During his entire reign, Napoleon, taking no notice of the miserable state of the Dutch economy, assumed that the Dutch were almost literally sitting on millions of guilders but refused to fulfill their financial duties. This misassumption dated back to the early French Revolution. ${ }^{43}$

Napoleon's rise to power also had its effects on Northwest Germany. The Hanseatic city-states struggled with their neutrality in 1799. The question of neutrality was considered of great importance for the future well-being of the urban communities. Politicians were greatly aware that neutrality, in practice, was only possible if the French and the British were convinced that their neutrality program served their own interests as well. The Hanseatic city-states were stuck between British and French demands and tried to offend neither party. For the time being, France was willing to respect their neutrality, as long as it was beneficial in (economic) warfare. ${ }^{44}$

In July 1800 a conflict started between the United Kingdom and neutral Denmark. The British demanded the right to search Danish vessels in open seas. Persuaded by 19 British warships in the Sound the Danish had to agree, whereupon Napoleon considered them to be unable to remain neutral. Napoleon urged Denmark to join forces with other neutral countries. ${ }^{45}$ Russian Tsar Paul I, seeing an opportunity to enlarge his sphere of influence, encouraged the Danish and Swedish governments to discuss matters, and also Prussia was invited to join Russia. Problematic was that the three smaller countries involved were traditional rivals and had serious conflicts of interest. Thus, on 16 and 18 December 1800, the three countries signed bilateral Neutrality Conventions with Russia, establishing the League of Armed Neutrality intended to resist British interference. ${ }^{46}$ The British, not amused, planned a preemptive naval attack on Copenhagen.

\footnotetext{
${ }^{42}$ François Crouzet, 'Aspects financiers de la relation franco-batave', in: A. Jourdan and J. Leerssen ed., Remous révolutionnaires: République batave, armée française (Amsterdam 1996) 56; Annie Jourdan, 'La république batave et le 18 brumaire: la grande illusion', Annales historiques de la Révolution française (1999) 763-764. https://doi.org/10.4000/ ahrf.301

${ }^{43}$ Annie Jourdan, 'Les Gaulois en Batavie: des relations diplomatiques machiavéliques', in: A. Jourdan and J. Leerssen ed., Remous révolutionnaires: République batave, armée française (Amsterdam 1996) 102.

${ }^{44}$ Aaslestad, Place and politics, 214.

${ }^{45}$ Eric Lerdrup-Bourgois, 'Napoléon et le Nord. Le Danemark-Norvège et la Suède', in: T. Lentz ed., Napoléon et l'Europe (Paris 2005) 343-346.

${ }^{46}$ Ole Feldbxk, 'The foreign policy of Tsar Paul I, 1800-1801: An interpretation', Jahrbücher für Geschichte Osteuropas 30 (1982) 21-26.
} 
British military superiority and the decease of Tsar Paul on 23 March 1801 made the league fall apart.

In their conflict with the British, between 29 March and 5 April 1801 Danish troops occupied Hamburg, Lübeck, and Travemünde and confiscated some British goods in the warehouses. However, after some weeks Prussia demanded the Danish withdraw, while the Prussians themselves intensified their presence in Northern Germany. ${ }^{47}$ Although brief, the Danish intervention ignited the public debate on the sustainability of neutrality. Several internal tensions came to the surface, which were linked to the question of whether or not to openly choose a side in the European wars. ${ }^{48}$

In the Netherlands, unease grew with the hostile tone of Napoleon. When the Batavians repeatedly proved unable to meet his demands, the First Consul decided to intervene. An orchestrated coup in September 1801 met with little resistance. Both French and Dutch hoped in particular that a new constitution would be sustainable and thereby guarantee peace. Napoleon rejected the idea of simply copying the French Constitution; to stress the autonomy of the Batavian Republic, the constitutional change had to be presented as genuinely Dutch, and aimed at political reconciliation. As in France, legislative power transitioned from the members of the Legislative Body to the executive, the collegial Staatsbewind-or 'Regency of State', consisting of 12 directors. This collegial government was in line with administrative tradition. The state was renamed 'Batavian Commonwealth', to give it a somewhat less revolutionary ring. Early modern symbols and institutions reappeared; for instance, the pre-revolutionary borders of the provinces were restored. Old elites also re-emerged. When former Stadholder William V gave up his claims to the Netherlands for a financial or territorial compensation, the way was paved for appeasement between moderate revolutionary and Orangists. Despite appearances, '1801' was not a radical break from the revolution. Although democratic institutions were largely abandoned, the Enlightenment ideals of freedom and equality were still praised by Dutch politicians. Moreover, the central government succeeded in firming its grip on local and provincial administrations. ${ }^{49}$

${ }^{47}$ Ole Feldbrk, The battle of Copenhagen 1801: Nelson and the Danes (Barnsley 2002) 230.

${ }^{48}$ Aaslestad, Place and politics, 220-221.

${ }^{49}$ L. de Gou ed., De Staatsregeling van 1801: bronnen voor de totstandkoming ('s-Gravenhage 1995) XX-XXVI.; Matthijs Lok and Martijn van der Burg, 'The Dutch case: The 
The idea of introducing a single head of state, in contradiction to Dutch tradition, was seen as unwanted. French ambassador Charles-Louis Huguet de Sémonville noticed the Batavians' aversion to a strong executive power. Governance in the Netherlands was not to be too 'French', Talleyrand and the First Consul stressed. ${ }^{50}$ Napoleon certainly remained keen to entice the Batavians to cooperate, as oppose to the use of force. He welcomed the new Batavian Ambassador Rutger Jan Schimmelpenninck with great pomp and circumstance, as did the Cambacérès and Lebrun; the latter would a few years later become a key player in the integration of the Netherlands into the Napoleonic Empire. ${ }^{51}$

\section{The Reorganization of Germany North of the Rhine}

Concerning the German lands, Bonaparte's approach was unconventional, certainly compared to the more prudent Talleyrand. Disregarding traditions, he developed many geopolitical redesigns in rapid succession following his victories on German soil. Of great importance was the Reichsdeputationshauptschluss, passed by the Imperial Diet of the Holy Roman Empire (Reichstag) on 25 February 1803, which was ratified a month later by Francis II, the last Holy Roman Emperor. This decision of the Diet, made under pressure from France and Russia, was a direct consequence of the French annexing of the Rhineland. Prussia and Austria had accepted the loss of these German lands but insisted that the princes who had been deprived of their lands would be compensated elsewhere in the Holy Roman Empire via the secularization of ecclesial possessions. During his Consulship, Napoleon actively intervened in the rearrangement of Germany prior to the Imperial Recess. Instead of merely secularizing German land, all ecclesiastical principalities were disbanded and Germany was 'mediatized'. Mediatization meant that almost all German states lost their 'imperial immediacy' (Reichsunmittelbarkeit). Prior to 1803, many free imperial cities and states had been placed under the immediate authority of the Holy Roman Emperor, without interference of

Kingdom of Holland and the imperial departments', in: M. Broers, P. Hicks and A. Guimerá ed., The Napoleonic empire and the new European political culture (Basingstoke 2012) 100-111. https://doi.org/10.1057/9781137271396_10

${ }^{50}$ Jourdan, 'Les Gaulois en Batavie: des relations diplomatiques machiavéliques', 107; L. de Gou ed., De Staatsregeling van 1801, XX-XXIII.

${ }^{51}$ Edwina Hagen, President van Nederland: Rutger Jan Schimmelpenninck, 1761-1825 (Amsterdam 2012) 171, 182. 
local princes. Given the political weakness of the Emperor, these states were virtually autonomous. The Reichsdeputationshauptschluss ended this traditional, feudal, mode of imperial governance, which for decades had been a thorn in the eyes of enlightened critics. Another goal was to draw borders more logically and create less dispersed states. For the time being, only the Hanseatic towns of Bremen, Hamburg, and Lübeck remained independent city-states, in addition to Augsburg, Frankfurt am Main and Nuremberg. ${ }^{52}$

Without a doubt, Prussia benefited from the restructuring. It received the northern parts of the former Duchy of Kleve (the parts on the left bank of the Rhine had been incorporated into France). In Northwest Germany the largest ecclesiastical state was the Prince-Bishopric of Münster. The Reichsdeputationshauptschluss secularized the region and divided it between the Duchy of Oldenburg (ruled by an uncle of the Tsar) and Prussia. Hanover was occupied by French forces. Two significant new principalities were established in the Northwest: the Duchy of Arenberg-Meppen was created, to compensate the Dukes of Arenberg who lost all Rhenish possessions to the French, which was also the case with the principality of Salm, ruled by the House of the same name. The Prince-Bishopric of Osnabrück was awarded to Hanover. Therefore, the British king also benefited, even though he had not lost any possessions on the left bank of the Rhine whatsoever. More to the South-east, Prince William Frederick of Orange, the son of the former Stadholder, received the former ecclesiastical principality of Fulda and some (even smaller) possessions, as a territorial compensation for the losses of the House of Orange due to the Batavian Revolution and the enlargement of France. Much to the disappointment of William Frederick, who had become an admirer of Bonaparte, his family would not receive financial compensation, nor was he awarded a more substantial principality. ${ }^{53}$

At first, mediatization did not seem all that harmful to the Hanseatic cities since their constitutional status remained virtually unchanged. However, they failed to get their neutral status recognized internationally. In May 1803, war broke out again between Great Britain and France. Hanover was occupied by French forces in June 1803, a clear violation of the North German demarcation line. Commander Jean-Baptiste

\footnotetext{
${ }^{52}$ Michel Kerautret, 'Les Allemagnes napoléoniennes', in: T. Lentz ed., Napoléon et l'Europe (Paris 2005) 325-328.

${ }^{53}$ Jeroen Koch, Koning Willem I, 1772-1843 (Amsterdam 2013) 125-135.
} 
Bernadotte, future king of Sweden, was appointed Governor of Hanover. Prussia would briefly gain Hanover as a reward for not siding with the Russians and Austrians during renewed hostilities. ${ }^{54}$ The French violated the neutrality of the Hanseatic cities, by seizing the district of Ritzebüttel, upon which Britain blockaded the Elbe, Weser, and Eider. This proved disastrous for the economy. Nevertheless, collectively the Hanseatic citystates continued to display their neutrality and peacefulness, hoping to stay out of harm's way. ${ }^{55}$

\section{Blueprints for Napoleonic Governance in Europe}

French revolutionary expansionism was an expression of interconnected ideas on nation, universal rights and the state, but revolutionary warfare in Europe also blurred the lines between 'liberation' and 'conquest'. The enlargement of France showed the difficulties of imposing rules and practices on hitherto foreign populations. The extent to which France had to impose itself was not determined. In the long term, Revolutionary France's expansion showed multiple ways in which pays conquis could be incorporated and integrated. Which policies were effective and which were counterproductive depended on local circumstances, but also on its implementation by various French actors. Thus, in an improvised manner, various types of governance blueprints were gradually conceived.

Europe was no tabula rasa. Well before Napoleonic interference, Dutch and Germans pondered how to improve state and society. Lack of consensus, or lack of means, had long obstructed durable changes. However, both for the Netherlands and for the Hanseatic city-states can be said that many foundations for later reforms were laid before the French intervened. The actions of Dutch Patriots, the open public sphere and discussion culture in Hamburg, and the willingness of local governments to learn, made that (urban) governance was certainly not 'archaic'. Differences were that the disputes in the Netherlands were more explicitly political in nature and more closely related to French developments. And, evidently, the question of centralization was much less prominent in Northwest Germany.

\footnotetext{
${ }^{54}$ Wright, Napoleon and Europe, 48.

${ }^{55}$ Aaslestad, Place and politics, 222-224.
} 
Meanwhile in France, Napoleon Bonaparte won people over to his cause and managed to secure the instruments for increased state-building. During the Consulate, he had assured Austrians and Prussians France would not to intervene in German affairs, in return for recognition of French rule on the left bank of the Rhine. And as long as neutral Prussia kept behind its side of the North German demarcation line, Napoleon allowed Prussian territorial expansion in the East. Also, Napoleon's interventions in the Netherlands initially took place mainly in the background. For the time being, the First Consul seemed satisfied with indirectly influencing other states by increasing the French sphere of influence. The historic Reichsdeputationshauptschluss, and successive coup d'états in the Batavian Republic, restructured governance North of the Rhine sufficiently, to his taste. Actual incorporation of Northern and Central Europe was not yet in France's interest. But progressively, supposedly natural borders in Europe became less relevant, which made the status of the Netherlands and Northwest Germany far from certain. Concurrently, the military was assigned a more pronounced role in the territorial ambitions of Napoleonic France.

In Belgium and the Rhineland, the French learned that foreign supporters were not ready to immediately accept all their beliefs. Given the drastic French measures, initially not too many locals were willing to collaborate. It had also become clear that hesitations could lead to delays. Winning the trust of the political elite was a pre-requisite, but also the general population could pose a threat, as became apparent when in both areas popular uprisings took place. In the first decade of the nineteenthcentury, new institutions would rather successfully be introduced, and a new generation would grow accustomed to them. On their turn, 'Belgian' and 'Rhenish' Frenchmen would later be sent to the Netherlands and Northwest Germany to promote integration. But first, the North had to be conquered and incorporated. The manner in which Dutch and Northwest German autonomy was lost, and its consequences for the subsequent implementation of Napoleonic governance, will be explored in the next chapter. 
Open Access This chapter is licensed under the terms of the Creative Commons Attribution 4.0 International License (http://creativecommons.org/licenses/ by $/ 4.0 /$ ), which permits use, sharing, adaptation, distribution and reproduction in any medium or format, as long as you give appropriate credit to the original author(s) and the source, provide a link to the Creative Commons licence and indicate if changes were made.

The images or other third party material in this chapter are included in the chapter's Creative Commons licence, unless indicated otherwise in a credit line to the material. If material is not included in the chapter's Creative Commons licence and your intended use is not permitted by statutory regulation or exceeds the permitted use, you will need to obtain permission directly from the copyright holder. 